\title{
Pengembangan Social Enterpreneurship Berbasis Budaya Lokal Menuju Kemandirian pada Panti Asuhan Al Amanah Gorontalo
}

\author{
Tri Handayani Amaliah, Mattoasi, Agus Hakri Bokingo \\ Universitas Negeri Gorontalo
}

\author{
E-mail: tri.handayani.amaliah@gmail.com \\ DOI: https://doi.org/10.21107/pangabdhi.v5i2.6106
}

\begin{abstract}
Abstrak
Panti Asuhan Al-Amanah tengah merintis usaha penjualan minyak wangi, namun pengelolaannya belum maksimal. Hal ini dilakukan guna mencukupi kebutuhan anak yatim piatu yang kini berjumlah 27 orang. Oleh karena itu, perlu adanya pelatihan dan pendampingan pada masyarakat panti agar wirausaha yang saat ini digeluti bisa semakin berkembang dan berkelanjutan. Permintaan pelatihan dan pendampingan dari mitra dapat diwujudkan melalui Program Kemitraan Masyarakat (PKM) ini bertujuan: 1) Mengembangkan kelompok masyarakat di Panti Asuhan Al-Amanah menjadi mandiri secara ekonomi dan sosial; 2) Membantu menciptakan ketentraman, kenyamanan dalam kehidupan bermasyarakat; 3) Meningkatkan keterampilan dalam berwirausaha sosial, dan 4) Sebagai upaya pelestarian budaya Gorontalo. Metode pendekatan yang dilakukan meliputi pendekatan partisipatif, ceramah, FGD (Focus Group Discussion), pendekatan kelompok dan individual. Tahapan kegiatan terdiri atas tahap persiapan, investigasi, pembekalan, pra-implementasi, evaluasi, dan implementasi. Pelatihan dan pendampingan yang dilakukan merupakan perjalanan muhibah yang dapat membentuk karakter berwirausaha sosial anak-anak panti sebagai bekal di masa yang akan datang khususnya dalam upaya melestarikan kebudayaan Gorontalo. Kegiatan ini berjalan tanpa hambatan dan mitra kini memperoleh pencerahan tentang manajemen usaha, pengelolaan administrasi dan keuangan serta penguasaan teknologi yang sangat bermanfaat untuk kegiatan promosi sehingga masyarakat luas dapat lebih mengenal dan mencintai produk parfum yang dijual oleh Panti Asuhan Al Amanah Gorontalo.
\end{abstract}

Artikel Diterima : 12 Agustus 2019/ Revisi : 7 September 2019/Terbit : 19 Oktober 2019

Kata kunci: Social Enterprenuership, Budaya, Panti Asuhan

\section{PENDAHULUAN}

Pengangguran tidak hanya terkait dengan kemiskinan, namun juga berhubungan erat dengan tindakan kriminalitas dalam masyarakat, seperti penyalahgunaan narkoba, pergaulan bebas, premanisme, jual beli manusia (human trafficking) yang akhir-akhir ini menjadi fenomena sosial di masyarakat (Utomo, 2014) Permasalahan yang tengah menggurita dalam kehidupan bermasyarakat di Indonesia tidak saja merupakan tanggung jawab Pemerintah akan tetapi juga sudah menjadi tanggung jawab seluruh bangsa Indonesia. Karenanya yang dibutuhkan saat ini adalah solusi yang dapat membantu dalam mengatasi permasalahan yang telah diuraikan di atas. Secara sederhana dapat dikatakan bahwa salah satu solusi yang dapat dilakukan untuk dapat keluar dari masalah terumit yang dihadapi pemerintah saat ini adalah dengan menumbuhkan dan membentuk karakter kewirausahaan sosial pada setiap lapisan indidvidu di masyarakat, terutama generasi muda yang merupakan tulang punggung bangsa (Ayob et.al., 2013; Utomo, 2014; Reginald dan Mawardi, 2014; Sofia, 2015).

Kebutuhan akan tenaga kerja yang berkualitas dalam era kompetitif dewasa ini harus diimbangi dengan terciptanya wirausahawan yang berkualitas, sehingga dengan semakin banyaknya jumlah wirausahawan yang berkualitas, maka jumlah lapangan kerja dan pendapatan ekonomi masyarakat pun ikut meningkat dan dengan sendirinya berdampak pada menurunnya jumlah pengangguran (Reginald dan Mawardi, 2014). Keinginan berwirausaha pada individu berperan penting untuk membangun niat dalam diri untuk melakukan wirausaha sosial (Ayob, et.al., 2013). Kewirausahaan sosial berbeda dengan kewirausahaan tradisional. Jika dalam kewirausaahan tradisional berfokus pada keuntungan materi serta kepuasan pelanggan, tidak demikian halnya fokus perhatian dalam kewirausahaan sosial yaitu misi sosial, produk atau service (Utomo, 2014). Social entrepreneurship meliputi empat elemen utama yaitu social value, civil society, innovation, and 
economic activity.

Social Value merupakan elemen paling khas dari social entrepreneurship, yakni penciptaan manfaat sosial yang nyata bagi masyarakat dan lingkungan sekitar. Civil Society pada umumnya berasal dari inisiatif dan partisipasi masyarakat sipil dengan mengoptimalkan modal sosial yang ada di masyarakat. Social Entrepreneurship memecahkan masalah sosial dengan cara-cara inovatif antara lain dengan memadukan kearifan lokal dan inovasi sosial. Economic Activity yang berhasil pada umumnya berkaitan dengan menyeimbangkan antara antara aktivitas sosial dan aktivitas bisnis. Aktivitas bisnis dan ekonomi dikembangkan untuk menjamin kemandirian dan keberlanjutan misi sosial organisasi (Palesangi, 2013 dalam Sofia, 2015).

Merujuk hasil wawancara dengan pimpinan panti (Bapak Moh. Kasim S. Ali) terungkap, saat ini untuk mencukupi kebutuhan hidup anak-anak yatim piatu di Panti Asuhan Al Amanah masih sangat bergantung pada bantuan dari donator yang kenyataannya belum memadai untuk dapat menopang segala kebutuhan hidup para anak panti yang kini berjumlah 27 orang. Hal inilah yang mendorong pimpinan Panti Asuhan $\mathrm{Al}$ Amanah untuk berinisiatif untuk melakukan wirausaha dengan menjajakan parfum sebagai penghasilan tambahan guna menutupi segala keperluan hidup sehari-hari anak panti yang menjadi tanggung jawabnya. Parfum tersebut ada yang langsung dijual kembali dan ada juga yang diracik terlebih dahulu untuk kemudian dijual kembali. Usaha penjualan parfum yang seyogyanya dapat dijadikan andalan ternyata tidak mampu berbicara banyak untuk menopang perekonomian Panti Asuhan Al Amanah. Hal ini diantaranya disebabkan karena adanya keterbatasan wawasan tentang manajemen usaha, kemampuan berkreasi dan melakukan inovasi terhadap produk yang dijual baik dalam desain kemasan maupun dalam hal promosi, serta kurangnya ketertarikan dan motivasi anak-anak panti dalam menjalani proses bisnis yang tengah digeluti. Kenyataan ini tidak dapat dipungkiri karena Panti Asuhan Al Amanah selama ini belum pernah memperoleh bimbingan dan pelatihan tentang manajemen wirausaha sosial. Pembinaan tentang manajemen usaha dalam kewirausahaan sosial sejak dini juga sangat diperlukan guna mendukung kemandirian pada anak serta menumbuhkan jiwa kewirausahaan sosial sejak dini. Mengingat dari segi usia anakanak di Panti Asuhan Al Amanah, sebagian besar berada pada usia pra remaja dan remaja. Usia tersebut merupakan usia produktif dan diharapkan saat ini mampu mengisi waktu yang dimiliki dengan berbagai aktivitas yang bermanfaat guna menambah pengetahuan dan wawasan keterampilan yang memadai. Dengan adanya pengetahuan dan wawasan keterampilan yang memadai kelak menjadi bekal untuk dapat bermetamorfosis menjadi pribadi mandiri yang tidak hanya dapat berguna bagi dirinya, namun juga mampu memberikan kemaslahatan bagi masyarakat dan alam semesta selepas dari kehidupan di Panti Asuhan.

Menyimak permasalahan yang tengah dihadapi Panti Asuhan Al Amanah merupakan permasalahan yang sangat mendesak untuk dicarikan solusinya. Permintaan pelatihan dan pendampingan dari mitra dapat diwujudkan melalui Program Kemitraan Masyarakat (PKM) ini yang bertujuan:

1. Mengembangkan kelompok masyarakat yang bernaung di Panti Asuhan Al-Amanah menjadi mandiri secara ekonomi dan sosial;

2. Membantu menciptakan ketenteraman, kenyamanan dalam kehidupan bermasyarakat;

3. Meningkatkan keterampilan dalam berwirausaha;

4. Sebagai upaya pelestarian budaya Gorontalo.

Secara operasional manifestasi dari tujuan tersebut meliputi:

a. Memberikan pencerahan tentang manajemen usaha yang baik dan memberikan motivasi kepada SDM yang dimiliki mitra agar dapat meningkatkan kreativitas untuk menciptakan produk yang berinovasi yang berkualitas, bermanfaat dan diterima pasar;

b. Meningkatkan wawasan mitra terkait pengelolaan administrasi, pengelolaan keuangan, pengelolaan modal kerja, pencatatan transaksi keuangan hingga pada tahap penyusunan laporan keuangan sederhana terhadap usaha yang tengah dirintis;

c. Meningkatkan pengetahuan tentang teknologi khususnya dalam tujuan promosi produk;

d. Pendampingan dalam pengurusan Izin usaha;

e. Meningkatkan motivasi dan menumbuhkan jiwa berwirausaha kepada mitra.

\section{METODE}

Pelaksanaan pengabdian pada masyarakat ini melibatkan mitra kerjasama, yaitu kelompok masyarakat yang terdapat pada Panti Asuhan Al Amanah di Desa Lomaya Propinsi Gorontalo.

Mekanisme tahapan kegiatan Program Kemitraan Masyarakat (PKM) terdiri atas enam tahapan, yakni tahap persiapan, investigasi, 
pembekalan, pra-implementasi, evaluasi, dan implementasi. Pada tahapan persiapan dilakukan survey lokasi dan koordinasi dengan mitra. Pada tahapan investigasi yang dilakukan adalah menggali komponen-komponen permasalahan yang tengah dihadapi mitra, mendengarkan berbagai keluhan mitra dalam menjalankan usahanya serta keinginan dan harapan mitra terhadap wirausaha yang tengah dirintisnya. Pada tahapan investigasi ini juga dilakukan identifikasi produk yang dimiliki mitra, menggali keterampilan, manajemen usaha, kegiatan administrasi dan pembukuan yang dimiliki mitra dan telah dijalankan dalam berwirausaha serta kegiatan promosi yang telah dilakukan.

Selain itu, pada tahapan investigasi ini juga akan digali potensi dan ide kreatif dari mitra yang belum terealisasi dan termanfaatkan. Sementara itu, tahapan pembekalan dibagi menjadi beberapa bagian, yaitu pembekalan pengembangan pembuatan produk unggulan melalui inovasi kemasan parfum, pembekalan pelatihan manajemen usaha, pembekalan sistem administrasi dan pembekalan penyusunan laporan keuangan sederhana, serta pembekalan perluasan jaringan pemasaran produk.

Sementara itu, pada tahap pra-implementasi dilakukan penerapan ilmu pengetahuan dan keterampilan yang telah diperoleh selama tahapan pembekalan. Pada tahapan ini juga digunakan untuk mengetahui nilai tambah dari kegiatan pengabdian PKM yang telah dilakukan. Pada tahapan ini dapat diketahui apakah masih terdapat hal-hal yang perlu untuk diperbaiki dan bagaimana cara penerapannya. Selanjutnya, pada tahap evaluasi dilakukan evaluasi hasil pra implementasi serta kendala-kendala yang dihadapi untuk dijadikan dasar dalam melakukan perbaikan.

Terakhir adalah tahapan implementasi yang merupakan penerapan secara berkelanjutan ilmu pengetahuan dan keterampilan yang telah diperoleh selama kegiatan pengabdian PKM berlangsung. Implementasi ilmu pengetahuan dan keterampilan yang diterapkan secara berkelanjutan diharapkan dapat mengembangkan kelompok masyarakat Panti Asuhan Al-Amanah menjadi mandiri secara ekonomi dan sosial, membantu menciptakan ketentraman, kenyamanan dalam kehidupan bermasyarakat, dan meningkatkan keterampilan dalam berwirausaha.

Pendekatan yang dilakukan untuk menyelesaikan persoalan mitra meliputi pendekatan partisipatif, metode pendekatan ceramah, pendekatan FGD (Focus Group Discussion), pendekatan kelompok dan individual.

a. Metode Pendekatan Partisipatif. Metode ini digunakan agar mitra dapat berpartisipasi aktif terhadap seluruh rangkaian kegiatan yang akan dilaksanakan. Pendekatan ini diawali dengan kegiatan bertemu secara langsung dengan pelaku usaha yang telah sukses. Hal ini dilakukan untuk memberikan motivasi, inspirasi, membangun niat, menumbuhkan semangat mitra untuk terus melakukan inovasi pengembangan usaha serta mengikuti dengan seksama proses kegiatan Program Kemitraan Kemasyarakatan (PKM).

b. Metode Pendekatan Ceramah. Cara yang paling efektif untuk memperkenalkan informasi atau konsep-konsep yang baru pada sekelompok orang yang belajar. Dalam metode pendekatan ini dilakukan presentasi mengenai konsep dan informasi dalam cara yang sistematis dalam waktu yang terbatas, menggunakan alat bantu, berdiskusi dengan mitra.

c. Metode Pendekatan FGD (Focus Group Discussion). Pada metode ini dilakukan sharing pengalaman dalam proses pembelajaran dengan cara: (a) Memberikan kesempatan kepada mitra untuk saling berbagi pengalaman, gagasan, ide, dan mengklarifikasi sudut pandang mitra yang berbeda (b) Membantu mitra mengenali apa yang mereka telah lakukan dan hal-hal yang mitra tidak ketahui (c) Membantu mitra menjawab pertanyaanpertanyaan yang selama ini mereka temui dalam pengalaman, meningkatkan keterlibatan mitra dalam menajalankan usahanya.

d.Pendekatan Kelompok dan Individual. Dalam metode pendekatan kelompok dan individual ini digunakan pembelajaran dengan melakukan pembelajaran melalui pengamatan. Hal-hal yang dilakukan adalah dengan pelatihan pengelolaan sistem administrasi, pelatihan penyusunan laporan keuangan sederhana, pelatihan pembuatan web/media sosial lainnya untuk kegiatan promosi. Di setiap akhir pelaksanaan kegiatan mitra diberikan angket untuk mengetahui seberapa besar tingkat pemahaman terhadap materi dan program yang telah diberikan.

\section{HASIL DAN PEMBAHASAN}

Keseluruhan tahapan pelaksanaan yang ditempuh tim pengabdi dalam mengatasi 
permasalahan mitra dapat berjalan efektif. Hal ini disebabkan tidak saja karena program-program yang telah dirancang oleh tim pengabdi memang merupakan program-program yang dibutuhkan, tetapi juga karena adanya dukungan dari pihakpihak pengurus panti dan para santri di Panti Asuhan Al Amanah yang merupakan mitra dalam program PKM ini. Agar pencapaian target yang telah ditetapkan dapat berjalan secara efektif, maka diperlukan program pendampingan yang dilakukan oleh tim pengabdi guna menentukan keberlanjutan program ini di masa yang akan datang. Hasil akhir dari adanya program-program tersebut diharapkan sangat berperan dalam mengangkat kesejahteraan dan kemandirian kelompok masyarakat Panti Asuhan Al Amanah Gorontalo.

\section{Mekanisme Tahapan Program Kemitraan Masyarakat (PKM)}

Tahapan Persiapan

Mekanisme tahapan kegiatan Program Kemitraan Masyarakat (PKM) terdiri atas tiga tahapan, yakni tahap persiapan, investigasi, pembekalan, pra-implementasi, evaluasi, dan implementasi. Setelah dilakukan tahapan persiapan, selanjutnya dilakukan tahapan investigasi.

\section{Tahapan Investigasi}

Tahapan investigasi dalam PKM ini dimaksudkan untuk menggali komponenkomponen permasalahan yang tengah dihadapi mitra, mendengarkan berbagai keluhan mitra dalam menjalankan usahanya serta keinginan dan harapan mitra terhadap wirausaha yang tengah dirintisnya. Pada tahapan investigasi ini juga dilakukan identifikasi produk yang dimiliki mitra, menggali keterampilan, manajemen usaha, kegiatan administrasi dan pembukuan yang dimiliki mitra dan telah dijalankan dalam berwirausaha serta kegiatan promosi yang telah dilakukan. Dalam melakukan tahapan investigasi diketahui bahwa produk yang dijual selama ini oleh Panti Asuhan Al Amanah adalah parfum non alkohol. Pengurus Panti Asuhan Al Amanah berinisiatif untuk menjual parfum agar memdapatkan penghasilan tambahan guna menutupi kebutuhan hidup sehari-hari anak panti yang menjadi tanggung jawabnya. Dalam kegiatan investigasi juga diketahui bahwa produk parfum yang dijajakan selama ini adalah biang parfum dan parfum racikan sendiri yang bahan dasarnya diperoleh dari Jawa. Selama ini untuk produk parfum yang diracik sendiri oleh Panti
Asuhan Al Amanah dijual dalam kemasan botol dengan ukuran $8 \mathrm{ml}, 15 \mathrm{ml}$ dan $30 \mathrm{ml}$. Wadah botol yang berisi parfum tersebut dijual tanpa menggunakan label kemasan, sehingga produk minyak wangi yang dijual belum memberikan ciri khas milik Panti Asuhan Al Amanah.

Selain itu, pada tahapan investigasi ini yang dilakukan terungkap bahwa realitas yang tengah dihadapi untuk mencukupi kebutuhan hidup anak-anak yatim piatu yang bernaung di Panti Asuhan Al Amanah saat ini masih sangat bergantung pada bantuan dari donator yang tentunya belum memadai untuk dapat menopang segala kebutuhan hidup para anak panti yang kini berjumlah 27 orang. Hal inilah yang mendorong pimpinan Panti Asuhan Al Amanah untuk berinisiatif berwirausaha dengan menjual minyak wangi/parfum sebagai Realitas yang ada, Panti Asuhan Al Amanah selama ini belum pernah mendapatkan bimbingan dan pelatihan tentang manajemen wirausaha sosial. Padahal pengebangan ilmu pengetahuan dan kreativitas dalam berwirausaha sangatlah penting untuk meraih going concern dalam usaha yang sedang digeluti. Sehingga usaha penjualan parfum dapat dijadikan andalan untuk menopang perekonomian Panti Asuhan Al Amanah. Adanya keterbatasan pengetahuan dan wawasan tentang manajemen usaha, keterbatasan kemampuan berkreasi dan melakukan inovasi terhadap produk yang dijual baik dalam desain kemasan maupun dalam hal promosi dapat menjadi batu sandungan untuk bisa bersaing di era saat ini. Tahapan investigasi yang dilakukan oleh tim pengabdi juga bertujuan untuk mengetahui program-program apa saja yang dibutuhkan dan menjadi skala prioritas dan belum pernah tersentuh di Panti Asuhan Al Amanah. Bekal ilmu pengetahuan dan keterampilan sangat dibutuhkan guna menunjang terwujudnya Panti Asuhan Al Amanah yang sejahtera dan mandiri.

Setelah dilakukan tahapan investigasi, maka selanjutnya tim pengabdi melaksanakan tahapan pembekalan yang diawali dengan melakukan koordinasi dalam upaya merancang kegiatan pengabdian, menyusun materi pengabdian sesuai dengan analisis kebutuhan mitra. Dalam konteks pemecahan suatu permasalahan yang sedang dihadapi, maka diperlukan penelusuran dari mana arah kebijakan digagas. Program Kemitraan Masyarakat (PKM) ini adalah sebuah perjalanan muhibah untuk dapat menerapkan ideide baru dalam memberdayakan masyarakat melalui program-program penting dan mendesak. Kegiatan pengabdian PKM ikut hadir dan 
bertujuan memberikan pengetahuan baru bagi masyarakat di Panti Asuhan Al Amanah, sebagaimana hasil survei awal tim pengabdi menemukan permasalahan yang dihadapi. Keterbatasan sumber daya, inovasi produk, dana dan pengetahuan tentang pengelolaan wirausaha yang baik menjadi kendala terbesar sehingga produk parfum yang menjadi unggulan panti perlu untuk dibenahi karena sebenarnya parfum Al Amanah milik panti memiliki peluang untuk menjadi lebih inovatif, dipasarkan secara lebih luas agar dapat bersaing dipasaran dan mampu mendongkrak pendapatan mereka.

Rangkain program kami hadir untuk menjembatani kepentingan masyarakat Panti Asuhan Al Amanah agar kreativitas dan keahlian mereka dapat memberikan penguatan ekonomi bagi keberlangsungan dan kesejahteraan masyarakat Panti Asuhan Al Amanah. Diharapkan pada masa yang akan datang melalui kegiatan ini dapat menghasilkan outcome sesuai yang dicita-citakan bagi peningkatan taraf hidup masyarakat tidak hanya di Panti Asuhan Al Amanah akan tetapi juga untuk masyarakat luas.

\section{Tahap Pembekalan}

Pada tahapan pembekalan dilakukan pengembangan pembuatan produk unggulan melalui inovasi kemasan parfum, pembekalan pelatihan manajemen usaha, pembekalan sistem administrasi dan pembekalan penyusunan laporan keuangan sederhana, serta pembekalan perluasan jaringan pemasaran produk. Sebagaimana telah disinggung sebelumnya bahwa tahapan pembekalan yang dilakukan dalam rangka untuk menyelesaikan persoalan mitra menggunakan pendekatan partisipatif, pendekatan ceramah, pendekatan FGD (Focus Group Discussion), serta pendekatan kelompok dan individual. Pendekatan ini ditempuh agar mitra dapat berpartisipasi aktif terhadap seluruh kegiatan yang dilaksanakan. FGD dalam kegiatan PKM ini diselenggarakan sebanyak dua kali. FGD yang pertama selain dimaksudkan untuk mensosialisasikan program-program PKM yang telah dirancang oleh Tim Pengabdian berdasarkan permasalahan-permasalahan yang dihadapi oleh mitra, FGD juga difungsikan sebagai sarana sharing pengalaman dalam proses pembelajaran dengan cara memberikan kesempatan kepada mitra untuk saling berbagi pengalaman, gagasan, ide, dan mengklarifikasi sudut pandang mitra yang berbeda, membantu mitra mengenali apa yang mereka telah lakukan dan hal-hal yang mitra tidak ketahui, membantu mitra menjawab pertanyaan-pertanyaan yang selama ini mereka temui dalam pengalaman dan meningkatkan keterlibatan mitra dalam menajalankan usahanya. Berikut disajikan rangkaian gambar kegiatan pembekalan:

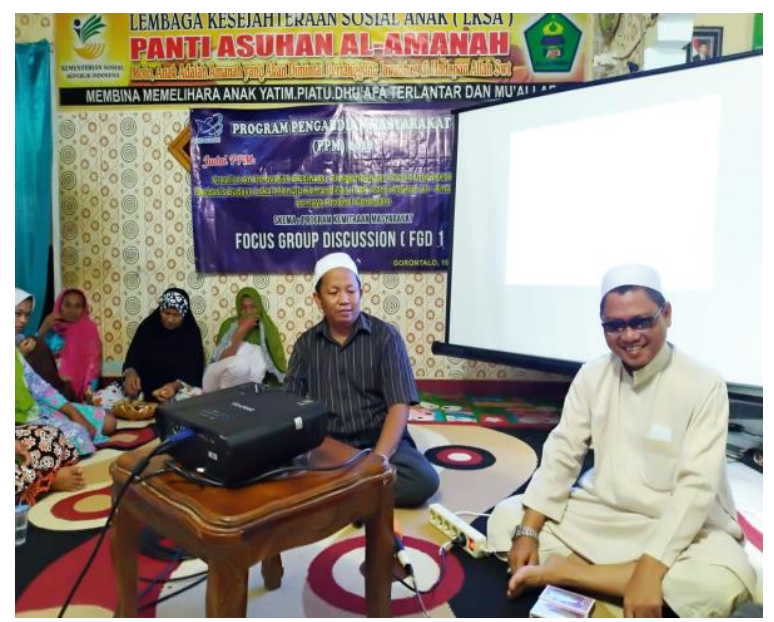

Gambar 1. Focus Group Discussion (FGD)

Dalam metode pendekatan FGD (Focus Group Discussion) dilakukan sharing pengalaman dalam proses pembelajaran dengan cara: a). Memberikan kesempatan kepada mitra untuk saling berbagi pengalaman, gagasan, ide, dan mengklarifikasi sudut pandang mitra yang berbeda. b) Membantu mitra mengenali apa yang mereka telah lakukan dan hal-hal yang mitra tidak ketahui c) Membantu mitra menjawab pertanyaan-pertanyaan yang selama ini mereka temui dalam pengalaman.

Sementara itu, pembekalan dalam pendekatan ceramah dilakukan penyajian materi tentang konsep dan informasi dalam cara yang sistematis dalam waktu yang terbatas, menggunakan alat bantu berupa laptop dan lcd serta berdiskusi dengan mitra. Kegiatan pembekalan tersebut mengagendakan pertemuan secara langsung dengan pelaku usaha yang telah sukses, bernama Ibu Sefya Kiyai, SE. Ibu Sefya adalah owner UD Cahaya Bintang Cakrawala sejak tahun 2012 hingga sekarang.

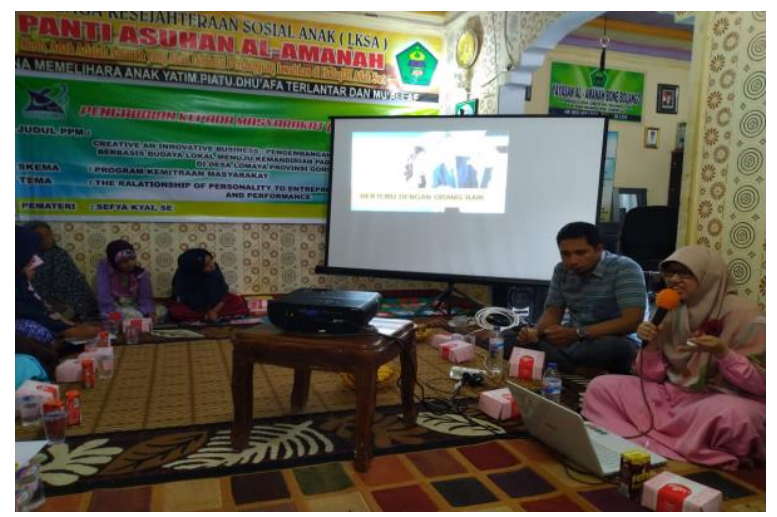


Gambar 2. Pendekatan Ceramah yang Dilakukan pada Tahapan Pembekalan

Pelaku usaha yang dihadirkan di Panti Asuhan Al Amanah adalah owner stik jagung di Gorontalo. Beliau hadir membawa misi untuk membangun motivasi anak-anak panti untuk memiliki semangat dan jiwa kewirausaahan seperti yang sedang digeluti saat ini dan meraih sukses. Selain itu Ibu Sefya juga memberikan inspirasi, membangun niat, menumbuhkan semangat mitra untuk terus melakukan inovasi pengembangan usaha serta mengikuti dengan seksama proses kegiatan Program Kemitraan Kemasyarakatan (PKM). Pengusaha muda sukses (Ibu Sefya Kyai, SE) dalam hal ini menyajikan materi yang berjudul The Relationship of Personality To Entrepreneurial Intentions And Performance" yang diberikan di kegiatan pembekalan.

Sebelum disajikan pelatihan tentang Manajemen Pemasaran, sebelumnya telah diberikan pelatihan Strategi Jitu Dalam Wirausaha Sosial" Dalam materi tersebut masyarakat panti diberikan pencerahan tentang apa yang dimaksud dengan wirausaha sosial dan perbedaannya dengan wirausaha tradisional serta strategi apa saja yang idealnya dilakukan untuk menjadikan kegiatan wirausaha yang dijalani dapat semakin berkembang dan berkelanjutan. Pembekalan berikutnya menyajikan pembekalan dalam hal administrasi dan akuntansi dalam berwirausaha sosial. Pada materi pembekalan kali ini masyarakat Panti Asuhan Al Amanah disuguhkan pencerahan tentang pengelolaan administrasi dan pencatatan transaksi keuangan secara sederhana hingga pada tahapan laporan keuangan dalam kegiatan wirausaha.

Pada proses pembekalan, selain masyarakat Panti Asuhan Al Amanah diberikan pelatihan tentang Inovasi Pengembangan Usaha, Strategi Berwirausaha Sosial, Manajemen Pemasaran, Administrasi dan Akuntansi Pengelolaan Usaha juga dilakukan sharing ilmu pengetahuan terkait tentang Pemasaran Online dan Staregi Promosi.

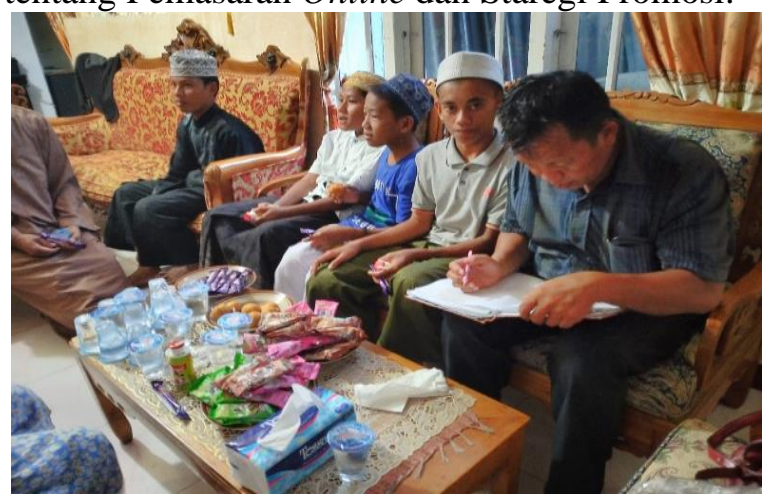

Gambar 3. Pendekatan Partisipatif Pada Tahap Pembekalan

Materi Pemasaran Online dan Strategi Promosi memberikan bekal ilmu pengetahuan bagaimana melakukan pemasaran produk secara praktis dan hemat biaya. Pada kesempatan tersebut diperagakan bagaimana cara membuat website dan strategi promosi produk dengan menggunakan media sosial. Pada pelatihan Pemasaran Online dan Strategi Promosi menghasilkan website dan fanpage Facebook Panti Asuhan Al Amanah.

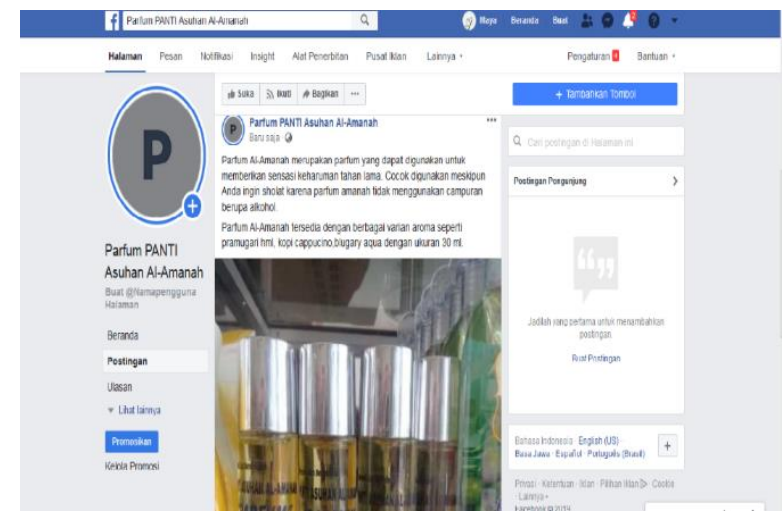

Gambar 4. Fanpage Facebook Parfum Panti Asuhan Al Amanah

Gambar Posting Artikel Dan Fanpage Facebook sebagaimana ditunjukkan pada gambar 5 dan 6 dibuat untuk memposting produk parfum Al Amanah sekaligus sebagai ajang promosi. Adanya website parfumalamanah.wordpress maka masyarakat umum dapat mengakses informasi tentang produk yang dipasarkan. Sementara itu dalam proses tahapan pra implementasi juga telah dihasilkan fanpage facebook dan website parfum Panti Asuhan Al Amanah. Hal ini merupakan laman yang berfungsi sebagai media untuk mempromosikan parfum milik Panti Asuhan Al Amanah sehingga tidak hanya masyarakat lokal Gorontalo yang dapat mengakses parfum yang dimiliki panti, namun juga dapat dijangkau oleh masyarakat luas. Tahapan pembekalan dalam PKM ini selain digunakan pendekatan partisipatif, metode ceramah, pendekatan FGD juga dilakukan pendekatan kelompok dan individual. Metode pendekatan kelompok dan individual ini dilakukan dengan proses pembelajaran melalui pengamatan. Materi pembelajaran mencakup pelatihan pengelolaan sistem administrasi, pelatihan penyusunan laporan keuangan sederhana, pelatihan pembuatan web/media sosial untuk kegiatan promosi.

Dalam melakukan proses tahapan pembekalan dengan metode individual dan kelompok terlihat 
antusias para santri Panti Asuhan Al Amanah dalam menimbah ilmu pengetahuan dan keterampilan yang diajarkan oleh Tim Pengabdi. Demi tercapainya tingkat pemahaman yang memadai terhadap materi pelatihan yang telah diberikan dalam kegiatan pengabdian PKM ini dan terimplementasinya keberlanjutan programprogram PKM yang telah dilakukan melalui sharing ilmu, maka pelaksanaan PKM juga mencakup upaya pendampingan tim pengabdi kepada masyarakat panti terhadap materi-materi yang telah diberikan.

Setelah melalui tahapan pembekalan, langkah selanjutnya yang dilakukan oleh tim pengabdi adalah melaksanakan tahapan Pra-Implementasi. Langkah ini merupakan kegiatan untuk menerapkan ilmu pengetahuan dan keterampilan yang telah diperoleh selama tahapan pembekalan. Pada tahapan ini juga dilakukan untuk mengetahui nilai tambah dari kegiatan pengabdian PKM yang telah disajikan. Pada tahapan ini juga akan diketahui apakah masih terdapat hal-hal yang perlu untuk diperbaiki dan bagaimana cara penerapannya. Sesuai dengan produk unggulan yang dijual oleh Panti Asuhan Al Amanah, pada tahapan pra implementasi tim pengabdi merancang desain kemasan botol parfum yang akan dilempar ke pasar. Pada tahapan ini berdasarkan hasil diskusi antara tim pengabdi dan tim pengelola Panti Asuhan Al Amanah dengan melihat dan menyimak harapan dan keinginan pihak pengelola Panti Asuhan Al Amanah maka lahirlah sebuah desain I (pertama) kemasan parfum seperti yang terlihat pada gambar berikut ini :

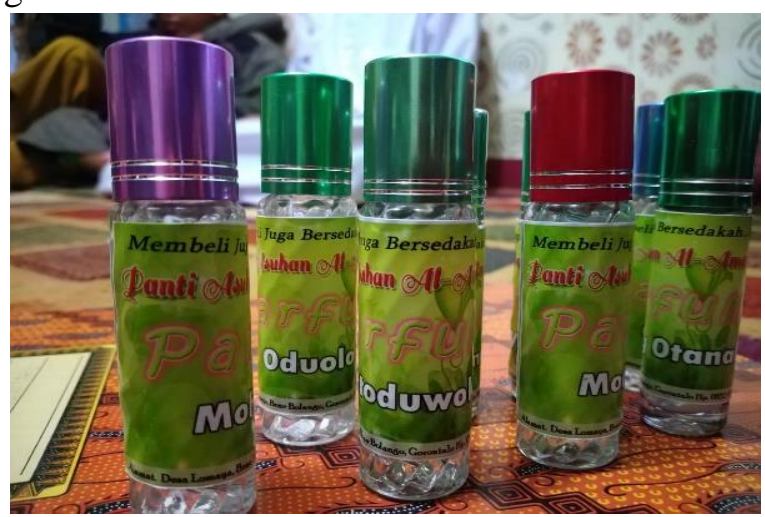

Gambar 5. Desain Produk Parfum Edisi 1

Desain kemasan parfum yang dihasilkan dari rumusan yang terlahir dari proses diskusi yang panjang antara tim pengabdi dan pihak pengelola panti asuhan bertuliskan informasi tentang nama panti asuhan, alamat panti, kata ungakapan "membeli dan bersedekah" dan kata-kata dalam bahasa Gorontalo disertai dengan artinya. Parfum ini kemudian diluncurkan ke pasar untuk melihat dan mengetahui respon pasar terkait dengan kemasan yang telah dilahirkan.

\section{Tahapan Pra Implementasi}

Pada tahapan Pra Implementasi dapat diketahui apakah masih terdapat hal-hal yang perlu untuk diperbaiki dan bagaimana cara penerapannya. Setelah mendengar dan menyimak tanggapan pasar dari beberepa konsumen dan calon kondumen, maka dilakukan diskusi secara berkelanjutan oleh tim pengabdi maupun diskusi antara tim pengabdi dan pihak pengurus Panti Asuhan. Koordinasi yang dilakukan bertujuan untuk menghasilkan desain kemasan botol parfum yang disesuaikan dengan keinginan dan kebutuhan pasar. Alhamdulillah Allah SWT memberikan kemudahan dalam perancangan desain yang diinginkan, maka berangkat dari hasil studi lapangan dan diskusi oleh tim pengabdi dan pihak pengelola panti, maka lahirlah desain kemasan parfum yang kedua, sebagaimana yang ditampilkan dalam gambar berikut ini:

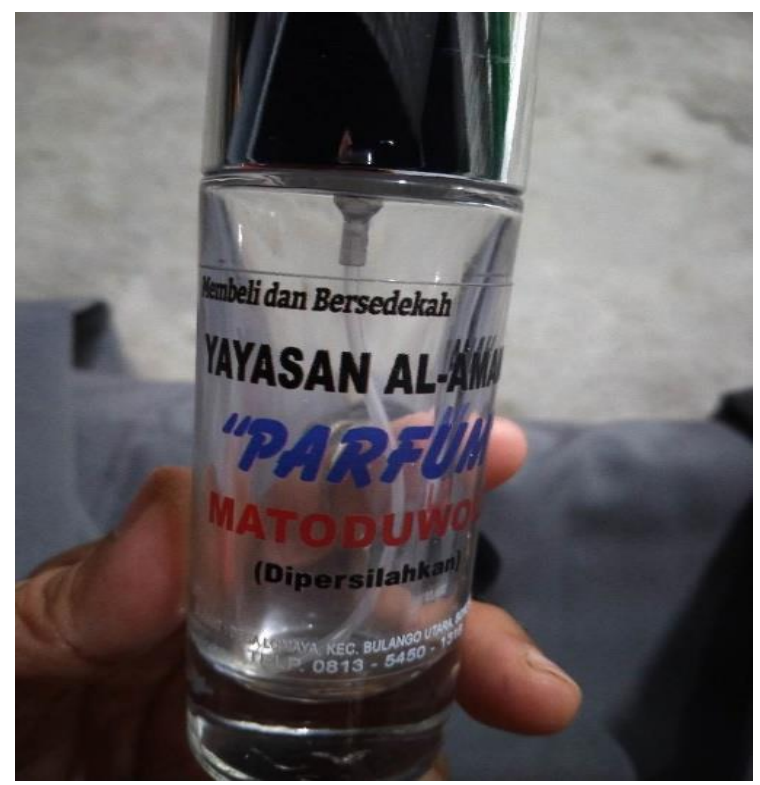

Gambar 6. Desain Kemasan Parfum Al Amanah

Setelah dihasilkan desain kemasan botol parfum yang terbaru, maka untuk selanjutnya tim pengabdi kembali turun ke lapangan untuk melihat bagaimana respon pasar khususnya terkait dengan desain kemasan parfum yang menjadi produk Panti Asuhan Al Amanah. Masukan terkait desain kemasan parfum yang diberikan oleh para konsumen, calon konsumen yang disesuaikan dengan keinginan pengurus panti sebetulnya bertujuan untuk menghasilkan kemasan parfum yang inovatif dan unik karena menampilkan budaya lokal masyarakat 
Gorontalo yang memang selama ini belum ada. Hal ini dilakukan untuk meraih cinta masyarakat Gorontalo maupun di luar Gorontalo, sehingga Parfum yang dihasilkan oleh Panti Asuhan Al Asmanah dapat diteima oleh masyarakat luas. Meskipun sebelumnya terdapat hal-hal yang harus ditinjau kembali untuk direvisi kembali. Penjualan parfum pada tahap pra implementasi diujicobakan untuk dijual secara door to door dan dipajang di etalase salah satu mini market yang ada di Gorontalo.

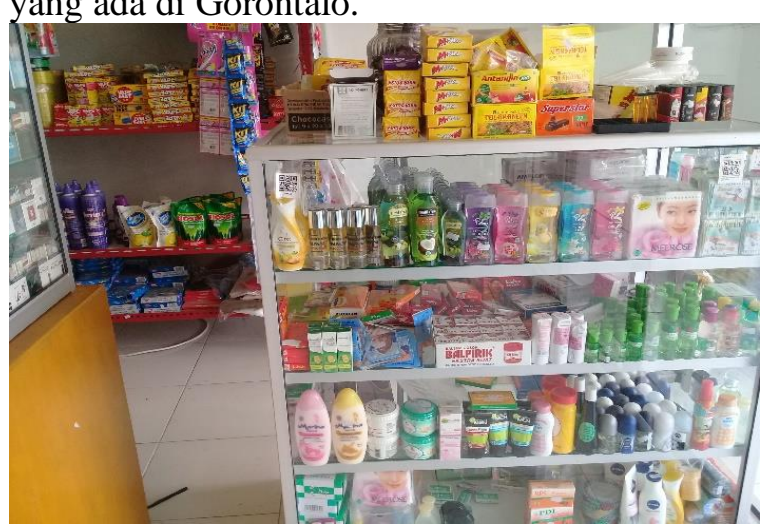

Gambar 7. Parfum Al Amanah Dipajang di Etalase Minimarket

Sebelum diluncurkan pada penjualan yang sesungguhnya pada tahapan implementasi melalui pemanfaatan e-marketing melalui akun jejaring sosial. Hasil penjualan parfum yang telah dititipkan kepada tim pengabdi selanjutnya diserahkan kepada pengurus Panti Asuhan. Beranjak dari rumusan kemasan yang terlahir melalui proses diskusi antara tim pengabdi dan pihak pengelola panti asuhan berdasarkan kebutuhan dan keinginan pasar akhirnya diluncurkan ke pasar desain kemasan parfum yang telah direvisi untuk kedua kalinya guna melihat dan mengetahui respon pasar terkait dengan kemasan yang telah dilahirkan. Sebagaimana masukan terkait kemasan parfum yang telah diberikan oleh para konsumen dan calon konsumen, satu hal yang tak kalah pentingnya untuk dipertimbangkan adalah terkait dengan biaya yang dibutuhkan per kemasan tidak terlalu tinggi, sehingga parfum yang dihasilkan oleh Panti Asuhan Al Amanah dapat melahirkan harga pokok yang memadai yang tentunya sangat menentukan terbentuknya harga jual. Dengan pertimbangan biaya, maka pada akhirnya dirumuskanlah desain parfum yang inovatif dan unik namun konsumen tidak perlu merogok kocek yang dalam untuk memiliki parfum yang diinginkan. Berikut ini ditampilkan gambar desain kemasan parfum yang telah direvisi sebanyak 3 kali:
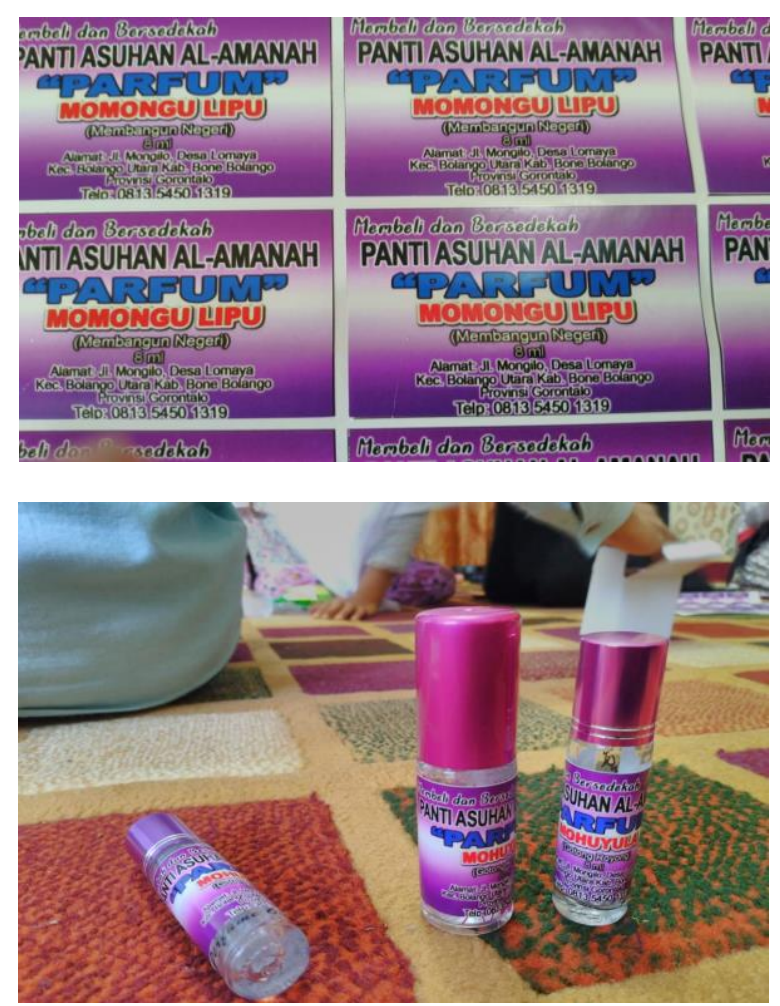

Gambar 8. Desain Parfum Al Amanah Edisi Revisi
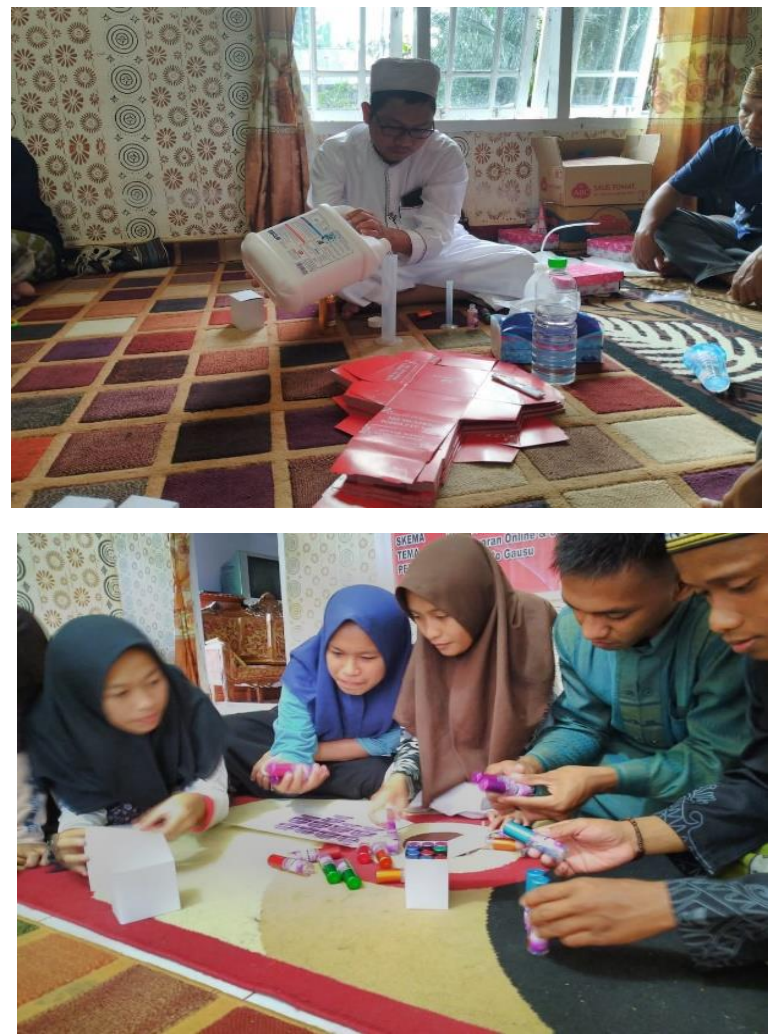

Gambar 9. Proses Pelabelan dan Peracikan Isi Parfum

Adapun ungkapan kata dalam Bahasa Gorontalo yang terucap dalam Parfum Al Amanah, diantaranya :

1. Matoduwolo = Dipersilahkan 
2. Mohuyula = Gotong Royong

3. Momongu lipu $=$ Membangun Negeri

4. Mongodulaa = Orang Tua

5. Mosadakah = Bersedekah

Melalui racikan desain kemasan parfum yang berasal dari rujukan para konsumen, pengelola Panti Asuhan Al Amanah dan pihak tim pengabdi, akhirnya diperolehlah desain kemasan parfum yang unik berbasis budaya kearifan lokal Gorontalo. Percikan kearifan lokal Gorontalo dimanifestasikan melalui ungkapan kata yang berbahasa daerah Gorontalo disertai dengan artinya. Apa yang terungkap dalam kemasan parfum sebenarnya menyampaikan pesan bagi para konsumen untuk senantiasa mencintai dan menjunjung tinggi bahasa daerah yang dimiliki, dalam hal ini bahasa daerah Gorontalo. Pesan ini tidak hanya ditujukan bagi masyarakat Gorontalo, namun juga untuk seluruh lapisan masyarakat pencinta parfum yang bukan berasal dari Gorontalo untuk mengenal Bahasa Gorontalo.

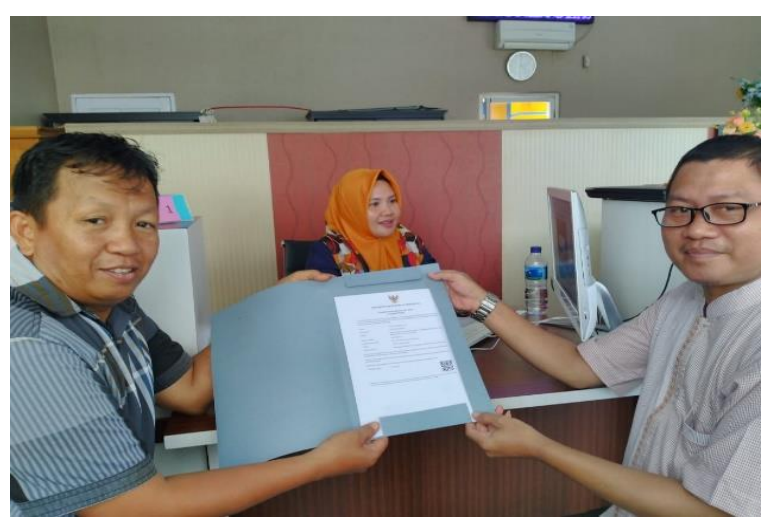

Gambar 10. Proses Pendampingan Pengurusan Ijin Usaha Mitra

Satu hal yang perlu untuk diungkapkan selain proses rumusan desain parfum yaitu upaya pendampingan yang dilakukan oleh tim pengabdi dalam rangka pengurusan izin usaha Panti Asuhan Al Amanah. Pengurusan ijin usaha Panti Asuhan Al Amanah Alhamdulillah berjalan lancar hingga terbitnya surat ijin usaha milik Panti Ashan tersebut.

\section{Tahap Evaluasi}

Setelah terciptanya desain kemasan parfum milik panti yang telah melalui beberapa kali revisi dan telah diterbitkannya surat ijin usaha panti, maka langkah selanjutnya adalah tahapan evaluasi. Tahapan evaluasi menggambarkan hasil yang diperoleh dari mulai tahapan pra implementasi yang telah dilakukan sejauh mana tingkat pemahaman terhadap apa yang disajikan pada tahap pembekalan serta kendala-kendala yang dihadapi untuk dijadikan dasar perbaikan selanjutnya.

Berdasarkan hasil pengamatan dan wawancara dengan pengelola dan anak-anak Panti Asuhan Al Amanah diketahui bahwa ratarata masyarakat panti telah memahami materimateri pembekalan yang telah disajikan, terlebih lagi dalam kegiatan pembekalan selain adanya pembekalan materi juga diselenggarakan pembekalan pendampingan. Adapun kendalakendala yang masih membutuhkan pemecahan persoalan lebih lanjut adalah adanya keterbatasan modal usaha, provider telekomunikasi belum menjangkau lokasi penjualan parfum, masih terbatasnya pengembangan jenis parfum baik aroma dan warna. Selain itu akses menuju Panti Asuhan Al Amanah saat ini masih terkendala dengan jalan yang rusak.

\section{Tahapan Implementasi}

Selanjutnya adalah tahapan implementasi. Tahapan ini merupakan penerapan secara berkelanjutan ilmu pengetahuan dan keterampilan yang telah diperoleh selama kegiatan pengabdian PKM berlangsung. Implementasi ilmu pengetahuan dan keterampilan yang diterapkan secara berkelanjutan diharapkan dapat mengembangkan kelompok masyarakat Panti Asuhan Al-Amanah menjadi mandiri secara ekonomi dan sosial, membantu menciptakan ketentraman, kenyamanan dalam kehidupan bermasyarakat, dan meningkatkan keterampilan dalam berwirausaha.

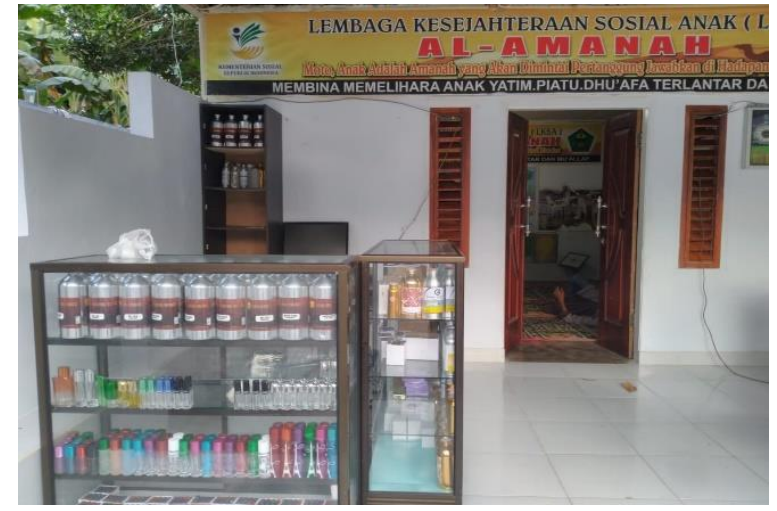

Gambar 11. Etalase Parfum di Panti Asuhan Al Amanah

Kegiatan pengabdian Program Kemitraan Masyarakat (PKM) ini merupakan perjalanan membawa misi untuk :

a. Membina dan mengembangkan kelompok masyarakat yang bernaung di Panti Asuhan AlAmanah menjadi mandiri secara ekonomi dan sosial,

b.Membantu menciptakan ketentraman, 
kenyamanan dalam kehidupan bermasyarakat

c. Meningkatkan keterampilan dalam berwirausaha melalui pendidikan dan pelatihan.

Setelah pelaksanaan kegiatan Program Kemitraan Masyarakat (PKM) selesai dilakukan, maka diharapkan kewirausahaan sosial yang digeluti oleh Panti Asuhan Al Amanah dapat semakin berkembang dan berkelanjutan sesuai dengan harapan bersama masyarakat Panti melalui bekal ilmu pengetahuan dan keterampilan yang telah dimiliki dari kegiatan PKM yang telah berlangsung. Terselenggaranya kegiatan Program Kemitraan Masyarakat (PKM) ini adalah sebagai upaya pengabdian masyarakat yang dilaksanakan oleh dosen di Panti Asuhan $\mathrm{Al}$ Amanah di Desa Lomaya Kecamatan Bulango Utara Provinsi Gorontalo diharapkan mendapat keberkahan hidup dari Allah SWT.

\section{KESIMPULAN}

Seluruh rangkaian kegiatan pengabdian Program Kemitraan Masyarakat (PKM) pada Panti Asuhan Al Amanah di Desa Lomaya Kecamatan Bulango Utara Provinsi Gorontalo telah berjalan dengan baik tanpa sesuatu kendala yang berarti. Melalui berbagai tahapan dan pendekatan yang dilakukan selain telah menghasilkan surat ijin usaha Panti Asughan Al Amanah juga melahirkan Sumber Daya Manusia (SDM) telah memahami bagaimana melakukan kewirausahaan sosial khususnya pada produk parfum dengan baik dan benar. Anak-anak Panti Asuhan Al Amanah di di Desa Lomaya Kecamatan Bulango Utara Provinsi Gorontalo ini telah memahami pentingnya melakukan pengelolaan yang baik dalam hal manajemen usaha, administrasi dan pengelolaan keuangan dan kegiatan promosi produk.

\section{Rekomendasi}

Program-program yang terdapat pada pengabdian PKM ini dapat berkelanjutan tidak hanya pada kelompok masyarakat di Panti Asuhan Al Amanah tetapi juga dapat diterapkan pada kelompok masyarakat di panti asuhan lainnya agar pemahaman konsep berwirausaha sosial dapat dipahami oleh seluruh lapisan masyarakat khususnya pada generasi muda yang terdapat di Panti Asuhan di Propinsi Gorontalo, sehingga Panti Asuhan yang ada di Gorontalo dapat semakin maju dan berkembang. Bekal ilmu pengetahuan dan keterampilan berwirausaha sosial sangat bermanfaat sebagai bekal yang dimiliki anak-anak Panti untuk mengurangi tingkat ketergantungan terhadap orang lain, menciptakan rasa kepercayaan diri, dan dapat meningkatkan daya tarik pelakunya. Kewirausahaan sosial juga dapat berperan sebagai menyediakan lapangan pekerjaan bagi masyarakat yang belum mendapatkan peluang kerja.

\section{DAFTAR PUSTAKA}

Ayob, N., Yap, C.S., Sapuan, D.A \& Rashid, A.R. (2013). Social Enterpreneurial Intention among Business Undergraduates: An Emerging Economy Perspective. Gadjah Mada International Journal of Business. Vol. 15, No.3. 249-267.

Dwivedi, A. (2004). Metodologi Pelatihan Partisipatif. Yogyakarta: Pustaka Yogya Mandiri.

Isbanah, Y., Kautsar, A., Prabowo, P.S. (2017). Membangun Kemandirian Financial Anak Panti Asuhan Melalui Pelatihan Kewirausahaan. ABDIMAS. Vol 21 (1). 153-159 pp.

Nasution, M.I., Prayogi, M.A \& Nasution, S.M.A. 2017. Pembinaan Manajemen Usaha Pada Pelaku Usaha Mikro Pengrajin Sepatu di Kecamatan Denai. Prosiding SNaPP2017 Sosial, Ekonomi, dan Humaniora. 90-97 pp.

Reginald, A.R., \& Mawardi, I. 2014. Kewirausahaan Sosial Pada Pondok Pesantren Sidogiri Pasuruan. JESTT. Vol.1, No.5. 333-345

Sledzik, K. 2013. Schumpeter"s View on Innovation and Entrepreneurship. Journal of Social Science Research Network.

Suherman, E. 2012. Kiat Sukses membangun SDM Indonesia. Bandung: Alfabeta.

Utomo, H. 2014. Menumbuhkan Minat Kewirausahaan Sosial. Among Makarti. Vol 7 (2). 1-16 pp.

Sofia, I.P. 2015. Konstruksi Model, Kewirausahaan Sosial (Social Enterpreneurship) Sebagai Gagasan Inovasi Sosial Bagi Pembangunan Perekonomian. Jurnal Universitas Pembangunan. Vol 2(1) 1-23 pp. 